\title{
DEVELOPMENT OF ENERGY EFFICIENT TECHNOLOGIES FOR BURNING COAL IN MODERN THERMAL POWER PLANTS AND EFFICIENCY ASSESSMENT TOOLS
}

\author{
Vitali Dubrovskiy ${ }^{1,}$, , Marina Zubova ${ }^{2}$, Nikolai Sedelnikov $^{1}$ and Anna Dihnova ${ }^{2}$ \\ ${ }^{1}$ National Research Tomsk Polytechnic University, 634050 Tomsk, Russia \\ ${ }^{2}$ Institute of Economics and Business Process Management, Department of Economics and Organization of energy \\ and transport sectors, Russia
}

\begin{abstract}
Universal ecological energy-efficient burner was described. The burner allows to burn different types of coal and lignite without the use of fuel oil for kindling the boiler. Efficiency assessment tools of the introduction of the burner for combustion of coal in modern thermal power plants were given.
\end{abstract}

\section{Introduction}

Modern methods of preparation and combustion of coal in thermal power plants do not completely meet the current requirements of reliability, environmental safety and economic efficiency of the boilers.

This fact raises the need to develop high-technology energy use of coal, aimed at a comprehensive solution to the problems of burning coals in modern thermal power plant, namely the exclusion of the use of expensive fuel oil, fuel oil, reducing the nitrogen oxides reduction in slagging of heating surfaces of boiler [1].

\section{Energy efficient technologies for burning coal}

Fig. 1 shows a sketch of a universal ecological energy-efficient burner.

Universal ecological energy-efficient burner device consists of a retort section which is heated for 15-20 minutes at the start of the boiler, silicon carbide heating elements to a temperature of 550$650{ }^{\circ} \mathrm{C}$. Then, coal dust is supplied in the burner device; it is gasified at the excess air coefficient which is significantly less than unity. After establishing a stable regime of the heating system it turns off automatically. A mixture of combustible gases and the coke particles is ignited and fed to combustion in the combustion chamber of the boiler at the outlet from the burner it is mixed with the secondary air.

Thus, the start of the boiler takes place without the use of expensive fuel oil, thus saving from 40 to 100 tons of fuel oil per kindling. Department of ecological energy-efficient burners can be successfully used with the boiler operating at low load, because flow of gasified coal dust is produced

a Corresponding author: vitdubrov@mail.ru 
in the volume of the burner and entering the combustion chamber of the boiler will serve as the backlight of the torch instead of currently used expensive liquid fuel - fuel oil.

An important novelty of the proposed incineration technology as opposed to analog is its focus on complex solution of problems of the energy efficient use of coal on the basis of universal burners with pre-flow gasification of coal dust in a muffle of the burner. The introduction of universal burners will significantly improve the efficiency of coal-fired thermal power plant units through integrated solutions of coal combustion in boiler units. Similar Russian and foreign developments usually solve maximum of two problems of burning coals.

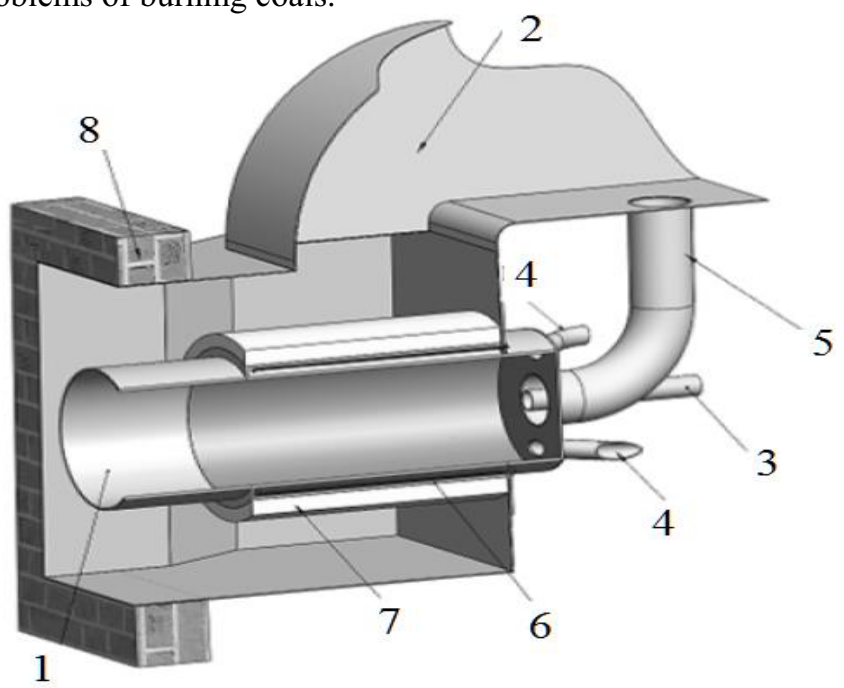

Figure 1. Sketch of the universal energy-efficient burner: 1 - part of the muffle; 2 - secondary air conduit; 3 device for supplying high concentration of dust; 4 - tangential primary air inlet; 5 - axial feed conduit of primary air; 6 - heating system; 7 - thermal insulation; 8 - boiler loophole.

The technology is designed to burn all types of highly reactive and brown coals, including Kansk-Achinsk and Kuznetsk Basin high-volatile coals, and can work with all types of boilers using coal fuel combustion chamber. Experience of development of the universal burner industrial design installed on the boiler BKZ-420-140 Krasnoyarsk RHPP-2 demonstrated the technical feasibility and a real opportunity to achieve the goals.

With full equipment of universal boilers burning devices a real opportunity to provide not only the Plasma-fuel firing the boiler will be achieved, as well: to reduce 2-3 times the emissions of nitrogen oxides; to stabilize the operation of the boiler at low loads; increase the utilization of installed capacity thermal power plants by reducing pollution and slagging of heating surfaces of boilers; provide a payback period for about three years.

\section{Efficiency assessment tools of ecological energy saving technologies}

Efficient energy use of coal from the Kansk-Achinsk basin due to a number of problems and in order to coals of Kansk-Achinsk basin could compete with other types of fuel (including gas), it is necessary to solve a number of major challenges in the development of new methods for the preparation and combustion ensuring high economic and environmental performance of energy equipment. It is necessary to develop more energy-efficient coal combustion technologies. It is extremely important that these technologies can be implemented in existing power plants with little capital investment. In this regard, relevant is the implementation of a new science-intensive technologies for burning coal, aimed at introducing ecological and energy efficient burners, allowing to organize the burning of coal in the existing boiler units so that solve the problems of environment and energy, stabilizes the boiler unit in a given mode [2]. 
To assess the effectiveness of the implementation of ecological and energy-saving technology to a power station it is necessary to consider projects simultaneously from two perspectives: local (independent investment projects to ensure the recoverability of the costs of their implementation by reducing the fuel component) and system-wide (elements of the system of fuel supply the country's Energy industry, the creation of which allows to reduce damage to the environment and improve the efficiency of energy use of fuel).

To assess social efficiency and to determine the prospects of replication technologies it should be modified to use Russia's energy model. This will provide new results on a system-wide definition of the effect of the implementation of energy efficient technologies, to justify the rational scale of development and to identify high-priority technology diffusion regions of Russia in the long term.

An important feature of the innovative projects financing is the probabilistic nature of income. As a result of feasibility studies for such projects should be risk-investment analysis.

In this regard, assessment of project risks mastering and replication of eco-energy saving technologies in modern thermal power plant should be carried out by a complex procedure consisting of identification and systematization of the risks of development and replication eco-energy saving technologies; methods of sensitivity analysis for the comparative assessment of the effect of individual factors on the final indicators of economic efficiency of the project; probabilistic method to determine expected, the most likely value of the integral economic effect; methods of scenario approach to determine the status of the project break-even point.

\section{References}

1. V. A. Dubrovsky, Improving the efficiency of energy use of Kansk-Achinsk coal basin (CPI KSTU, Krasnoyarsk, 2004) [in Russian]

2. V. A. Dubrovsky, M. V. Zubova, Energy-efficient lighting and kindling the flame combustion chambers of boilers (Teplotechnik, Moscow, 2012) [in Russian] 